\title{
Homeless and Foster Youth, Racial Inequity, and Policy Shifts for Systemic Change
}

James Dean Ward

Heidi Booth 


\section{ITHAKA S+R}

Ithaka $\mathrm{S}+\mathrm{R}$ provides research and strategic guidance to help the academic and cultural communities serve the public good and navigate economic, demographic, and technological change. Ithaka $\mathrm{S}+\mathrm{R}$ is part of ITHAKA, a not-for-profit organization that works to advance and preserve knowledge and to improve teaching and learning through the use of digital technologies. Artstor, JSTOR, and Portico are also part of ITHAKA.

Copyright 2021 ITHAKA. This work is licensed under a Creative Commons Attribution 4.0 International License. To view a copy of the license, please see https://creativecommons.org/licenses/by/4.0/.

ITHAKA is interested in disseminating this brief as widely as possible. Please contact us with any questions about using the report: research@ithaka.org.

We thank the Pullias Center for Higher Education at the University of Southern California for its support of this research. 
Each year, roughly 4.2 million young people experience homelessness, and more than 600,000 children interact with the foster care system nationwide. ${ }^{1}$ Although youth homelessness and foster care are distinct experiences, many youth will crossover between these two groups. Both groups also face similar challenges, including highly unstable living environments, food insecurity, and often gaps in educational achievement and attainment.

While the legal definition of youth homelessness varies across states and targeted policies, the Department of Education defines homeless youth as "individuals who lack a fixed, regular, and adequate nighttime residence." 2 This can include, but is not limited to, youth living in shelters, cars, public spaces, or doubled up with other families. Youth who meet this definition and are also not living with a parent or guardian are considered "unaccompanied youth." 3 Foster care offers a temporary placement for children who cannot live with their families. While in foster care, youth may live with related or unrelated foster parents or in group homes, shelters, residential care facilities, or supervised independent living arrangements. ${ }^{4}$ Although homeless and foster youth are distinct groups, they share many attributes and experiences.

Both foster and homeless youth are disproportionately Black. While only 14 percent of youth nationwide identify as Black or African American, 38 percent of homeless youth and 23 percent of children in foster care are Black. 5 Not only are Black children more likely to enter foster care, they tend to remain in foster care longer, are more likely to experience frequent placement changes, and are less likely to be reunified with their birth parents. ${ }^{6}$

Considering the economic benefits of a college degree, higher education can be particularly beneficial for homeless and foster youth. However, homeless youth are less likely to enroll in college, and nearly three quarters of foster youth who begin college do not complete a degree or certificate within six years. 7 This policy brief seeks to better understand the challenges that homeless and foster youth face in earning a postsecondary degree, particularly youth from

\footnotetext{
${ }^{1}$ Children's Bureau, "The AFCARS Report No. 27," U.S. Department of Health and Human Services, August 24, 2020, https://www.acf.hhs.gov/cb/report/afcars-report-27; M. A. Hull, H. Morton, S. Patel, S. Curry, and E. Carreon, "Missed Opportunities: Education among Youth Experiencing Homelessness in America," Chapin Hall at the University of Chicago, November 2019, https://eric.ed.gov/?id=ED603015.

${ }^{2}$ Subtitle VII-B of the McKinney-Vento Homeless Assistance Act.

${ }^{3}$ National Center for Homeless Education, "Supporting the Education of Unaccompanied Students Experiencing Homelessness," August 2017, https://files.eric.ed.gov/fulltext/ED594667.pdf.

${ }^{4}$ Children's Bureau, "Foster Care," Administration for Children \& Families, January 25, 2021, https://www.acf.hhs.gov/cb/focusareas/foster-care.

${ }^{5}$ Child Welfare Information Gateway, "Foster Care Statistics," Department of Health and Human Services, May 2020, https://www.childwelfare.gov/pubPDFs/foster.pdf; Safe Horizon, "Youth Homeless Statistics \& Facts," 2021, https://www.safehorizon.org/get-informed/homeless-youth-statistics-facts/\#statistics-and-facts/.

${ }^{6}$ Reiko Boyd, "African American Disproportionality and Disparity in Child Welfare: Toward a Comprehensive Conceptual Framework," Children and Youth Services Review 37 (2014): 15-27, https://doi.org/10.1016/j.childyouth.2013.11.013.

${ }^{7}$ M. A. Kull, M. H. Morton, S. Patel, S. Curry, and E. Carreon. "Missed Opportunities: Education among Youth Experiencing Homelessness in America." Chapin Hall at the University of Chicago, November 2019, https://eric.ed.gov/?id=ED603015; GAO, "Actions Needed to Improve Access to Federal Financial Assistance for Homeless and Foster Youth," May 19, 2016, https://www.gao.gov/products/GAO-16-343.
} 
racial/ethnic minority groups. In addition, we will recommend a policy framework for states to improve the postsecondary outcomes of homeless and foster youth.

\section{What political, economic, and social factors increase the likelihood of homelessness and foster care?}

Before we discuss the educational experiences of homeless and foster youth, it is important to understand the underlying causes of homelessness and foster system involvement and how racial/ethnic minority youth disproportionately encounter these experiences. The racial disparities inherent in youth homelessness and foster care involvement are the result of-and exacerbated by-layers of political, economic, and social inequality. Segregation, mass incarceration, and job and housing discrimination all contribute, either directly or through their impact on economic insecurity, to the disproportionate number of Black and Hispanic youth in foster care or experiencing homelessness. In this section we present the links between homelessness and foster care, and then discuss the policies that contribute to the disproportionate representation of Black and Hispanic youth in these populations.

\section{The bi-directional pipeline between homelessness and foster care}

Although foster and homeless youth populations differ in important ways, there are important connections between these two statuses. Black youth are much more likely than non-Black youth to enter the foster care system, in large part due to individual and structural racism in the child welfare system. One contributing structural factor is "visibility bias." Black families and children participate in government assistance programs at higher rates than other racial/ethnic groups, making them more "visible" to mandated reporters and thus reported at higher rates. ${ }^{8}$ However, at the individual level, studies also suggest the presence of racial bias in caseworkers' perception of child neglect and in their decisions to substantiate reports of child maltreatment. 9 As a result, Black families are both more likely to be reported and investigated for child maltreatment, and caseworkers are more likely to substantiate reports of maltreatment within Black households. ${ }^{10}$ The social services intended to help needy families, including those experiencing homelessness, can increase the likelihood of youth entering the foster care system.

\footnotetext{
${ }^{8}$ Sheila D. Ards, Samuel L. Myers Jr, Patricia Ray, Hyeon-Eui Kim, Kevin Monroe, and Irma Arteaga, "Racialized Perceptions and Child Neglect," Children and Youth Services Review 34, no. 8 (2012): 1480-1491, https://doi.org/10.1016/j.childyouth.2012.03.018; Reiko Boyd, "African American Disproportionality and Disparity in Child Welfare: Toward a Comprehensive Conceptual Framework," Children and Youth Services Review 37 (2014): 15-27, https://doi.org/10.1016/j.childyouth.2013.11.013.

${ }^{9}$ Sheila D. Ards, Samuel L. Myers Jr, Patricia Ray, Hyeon-Eui Kim, Kevin Monroe, and Irma Arteaga, "Racialized Perceptions and Child Neglect," Children and Youth Services Review 34, no. 8 (2012): 1480-1491, https://doi.org/10.1016/j.childyouth.2012.03.018; Alan J. Dettlaff, Stephanie L. Rivaux, Donald J. Baumann, John D. Fluke, Joan R. Rycraft, and Joyce James, "Disentangling Substantiation: The Influence of Race, Income, and Risk on the Substantiation Decision in Child Welfare," Children and Youth Services Review 33, no. 9 (2011): 1630-1637, https://doi.org/10.1016/j.childyouth.2011.04.005.

10 Jina Lee, Zenobia Bell, and Mae Ackerman-Brimberg, "Implicit Bias in the Child Welfare, Education and Mental Health Systems," National Center for Youth Law, 2015, http://www.centerforchildwelfare.org/kb/cultcomp/lmplicit-Bias-in-Child-WelfareEducation-and-Mental-Health-Systems-Literature-Review 061915.pdf.
} 
Foster youth are also more likely to experience homelessness than other youth. Roughly onethird of homeless youth have experience with the foster system, and when foster youth age out of the system, between one third and one half of them experience homelessness soon after. ${ }^{11}$ Foster youth often run away from their placement homes to avoid abuse, authoritative or strict environments, and general negative interaction with foster peers, families, or staff. ${ }^{12}$ Black and Hispanic youth are more likely than their white foster peers to run away, potentially resulting from additional stresses related to their racial or ethnic identities. ${ }^{13}$ The patterns suggest a pipeline from foster care to homelessness, especially among individuals aging out of the foster system. Moreover, homeless youth with a history of foster care experience longer periods of homelessness and report higher levels of abuse. ${ }^{14}$ The compounded effects of the foster to homeless pipeline can further limit opportunities for these youth.

\section{Policies contributing to homelessness and foster care involvement}

Racial segregation exacerbates youth homelessness and poverty, which are inextricably related, as it contributes to persistent income inequality and poverty disproportionately affecting Black populations. ${ }^{15}$ Broadly speaking, segregation in both housing and education have limited educational and economic opportunities for Black individuals and families. It is important to acknowledge the central role that state and federal policy have played in both creating and maintaining racial segregation. ${ }^{16}$ Jim Crow laws, the exclusion of Black males from the GI Bill, the use of redlining by the Federal Housing Administration, and the more recent participation of government regulators in "reverse redlining" are a few examples of federal policy decisions that have restrained Black families' intergenerational wealth relative to white families. A lack of inherited wealth means Black individuals and families today are less likely to have a financial cushion to fall back on in the case of a job loss or other financial crisis. ${ }^{17}$ This financial precarity puts them at greater risk of experiencing homelessness.

\footnotetext{
${ }^{11}$ Matthew H. Morton, Amy Dworsky, and Gina Miranda Samuels, "Missed Opportunities: Youth Homelessness in America. National Estimates," Chapin Hall at the University of Chicago, 2017, https://voicesofyouthcount.org/brief/national-estimates-of-youthhomelessness/; Amy Dworsky, Laura Napolitano, and Mark Courtney, "Homelessness during the Transition from Foster Care to Adulthood," American Journal of Public Health 103, no. S2 (2013): S318-S323, https://www.ncbi.nlm.nih.gov/pmc/articles/PMC3969135/.

${ }^{12}$ Kimberly Crosland and Glen Dunlap, "Running Away from Foster Care: What Do We Know and What Do We Do?" Journal of Child and Family Studies 24, no. 6 (2015): 1697-1706, https://doi.org/10.1007/s10826-014-9972-x.

${ }^{13}$ Amy Dworsky, Fred Wulczyn, and Lilian Huang, "Predictors of Running Away from Out-of-Home Care: Does County Context Matter?" Cityscape 20, no. 3 (2018): 101-116, https://www.huduser.gov/portal/periodicals/cityscpe/vol20num3/ch5.pdf.

${ }^{14}$ Kimberly Bender, Jessica Yang, Kristin Ferguson, and Sanna Thompson, "Experiences and Needs of Homeless Youth with a History of Foster Care," Children and Youth Services Review 55 (2015): 222-231, https://doi.org/10.1016/j.childyouth.2015.06.007.

${ }^{15}$ Elizabeth Oltmans Ananat, "The Wrong Side(s) of the Tracks: The Causal Effects of Racial Segregation on Urban Poverty and Inequality," American Economic Journal: Applied Economics 3, no. 2 (2011): 34-66, www.doi.org/10.1257/app.3.2.34.

${ }^{16}$ Richard Rothstein, The Color of Law: A Forgotten History of How Our Government Segregated America, Liveright Publishing, 2017, https://www.epi.org/publication/the-color-of-law-a-forgotten-history-of-how-our-government-segregated-americal.

17 Thomas Shapiro, Tatjana Meschede, and Sam Osoro, "The Roots of The Widening Racial Wealth Gap: Explaining the BlackWhite Economic Divide," February 2013, https://drum.lib.umd.edu/bitstream/handle/1903/24590/racialwealthgapbrief.pdf?sequenc.
} 
The increase in the number of homeless youth is a direct consequence of policy decisions. Increasing housing costs and a shrinking supply of affordable housing also contribute to increased homelessness. A recent study found that in Michigan a $\$ 100$ increase in rent was associated with a 12 percent increase in the number of homeless students in the K-12 context. ${ }^{18}$ Rental assistance programs such as housing vouchers can successfully reduce homelessness and housing instability. ${ }^{19}$ However, the majority of eligible families do not receive federal housing assistance due to funding limitations, and public spending on housing disproportionately favors higher-income households in the form of homeowner tax credits rather than housing vouchers to lower-income renters. ${ }^{20}$

In addition to policies that create and maintain economic inequality, policies that disproportionately separate racial/ethnic minority families, including deportation and incarceration, also increase the likelihood of homelessness and foster care for Black and Hispanic youth in particular. "Tough on crime" policies that have contributed to mass incarceration are one such example. A study on the consequences of mass incarceration suggests that paternal incarceration leads to higher risk of youth homelessness and that this effect is concentrated in African American youth..$^{21}$ Immigration policy and enforcement of deportation can also serve to separate families and increase the need for foster care services. Between 2001 and 2015, an increase in immigration enforcement was associated with a 15 to 21 percent increase in the share of Hispanic youth entering foster care. ${ }^{22}$

Social factors such as housing discrimination and inequitable access to healthcare can also be contributors to homelessness, especially for Black families. Although racial discrimination in housing is illegal under the Fair Housing Act, Black families continue to face layers of discrimination that make both renting and owning a home more difficult and often more expensive. Lenders deny mortgages to Black borrowers at higher rates and charge them higher fees and interest rates. ${ }^{23}$ A 2012 HUD survey also revealed that realtors show Black and other

\footnotetext{
${ }^{18}$ Michael Evangelist and H. Luke Shaefer, "No Place Called Home: Student Homelessness and Structural Correlates," Social Service Review 94, no. 1 (2020): 4-35, https://doi.org/10.1086/707569.

${ }^{19}$ Will Fischer, "Research Shows Housing Vouchers Reduce Hardship and Provide Platform for Long-Term Gains among Children," Washington, DC: Center on Budget and Policy Priorities, October 7, 2015, https://www.cbpp.org/sites/default/files/atoms/files/3-10-14hous.pdf.

${ }^{20}$ Michael Evangelist and H. Luke Shaefer, "No Place Called Home: Student Homelessness and Structural Correlates," Social Service Review 94, no. 1 (2020): 4-35, https://doi.org/10.1086/707569; Will Fischer and Barbara Sard, "Chart Book: Federal Housing Spending Is Poorly Matched to Need," Washington, DC: Center on Budget and Policy Priorities, March 8, 2017, https://www.cbpp.org/sites/default/files/atoms/files/12-18-13hous.pdf.

${ }^{21}$ Christopher Wildeman, "Parental Incarceration, Child Homelessness, and the Invisible Consequences of Mass Imprisonment," The ANNALS of the American Academy of Political and Social Science 651, no. 1 (2014): 74-96, https://doi.org/10.1177\%2F0002716213502921.

${ }^{22}$ Catalina Amuedo-Dorantes and Esther Arenas-Arroyo, "Immigration Enforcement and Foster Care Placements," July 10, 2017, https://papers.ssrn.com/sol3/papers.cfm?abstract id=2998959.

${ }^{23}$ Los Angeles Homeless Services Authority, "Report and Recommendations of the Ad Hoc Committee on Black People Experiencing Homelessness," December 2018, https://www.lahsa.org/documents?id=2823-report-and-recommendations-of-the-adhoc-committee-on-black-people-experiencing-homelessness.
} 
minority renters fewer units than similarly qualified white renters. ${ }^{24}$ Black adults are also less likely to have access to mental health services. ${ }^{25}$ Untreated mental illnesses can lead to higher rates of unemployment, which is a leading cause of homelessness. ${ }^{26}$

These broader systems of inequality perpetuate the disproportionate rates of homelessness and foster care among Black and Hispanic youth. Segregation, mass incarceration, and job and housing discrimination all negatively affect Black and Hispanic communities, and have throughout American history. The economic inequality that results from these systematic forces has left more Black and Hispanic youth in financially precarious situations either directly through homelessness or via the foster system. This also highlights the potential that racial and ethnic minority youth experiencing homelessness or who are involved in the foster system are doubly disadvantaged by general social inequality. Understanding these broad forces underscores the importance of policy solutions that target the most disadvantaged members of society.

\section{What are the experiences of homeless and foster youth that influence their educational outcomes?}

The challenges and instability that come with homelessness and foster care can hinder educational progress. These challenges follow students throughout the PK-20 pipeline, but manifest differently across contexts. Moreover, there is a compounding effect throughout the pipeline that results in homeless and foster youth having lower postsecondary attainment than their peers. Students who may face higher rates of disciplinary action and truancy during PK-12 are less likely to graduate and attend college. In this section, we examine the unique experiences of homeless and foster youth in the PK-12 system as well as in higher education. We also consider how racial/ethnic identity can doubly disadvantage students due to systemic biases in the education system.

\section{PK-12 student experiences}

Homeless and foster youth experience more disruptions in their education, which negatively affects their achievement and likelihood of completing high school. Foster youth in particular are disproportionately likely to be suspended or expelled, potentially up to three times as frequently as non-foster youth. ${ }^{27}$ Among homeless youth, high rates of chronic absenteeism and

\footnotetext{
${ }^{24}$ Margery Austin Turner, Rob Santos, Diane K. Levy, Doug Wissoker, Claudia Aranda, and Rob Pitingolo, "Housing Discrimination against Racial and Ethnic Minorities 2012: Executive Summary," Urban Development, Policy Development, and Research, June 2013, https://www.huduser.gov/portal/Publications/pdf/HUD-514 HDS2012.pdf.

${ }^{25}$ American Psychological Association, "African Americans Have Limited Access to Mental and Behavioral Health Care," September 2017, https://www.apa.org/advocacy/civil-rights/diversity/african-american-health.

${ }^{26}$ American Association of Child \& Adolescent Psychiatry, "Improving Access to Mental Health: Reducing Mental Health Stigma," 2019, https://www.aacap.org/App Themes/AACAP/docs/Advocacy/policy resources/Improving-Access-Stigma.pdf;

National Law Center on Homelessness and Poverty, "Homelessness in America: Overview of Data and Causes," October 2015, https://nlchp.org/wp-content/uploads/2018/10/Homeless Stats Fact Sheet.pdf.

${ }^{27}$ Tracey G. Scherr, "Educational Experiences of Children in Foster Care: Meta-Analyses of Special Education, Retention and Discipline Rates," School Psychology International 28, no. 4 (2007): 419-436, https://doi.org/10.1177\%2F0143034307084133.
} 
high rates of disciplinary action are especially concerning. ${ }^{28}$ Students experiencing homelessness are more than twice as likely as their peers to be chronically absent and more than three times as likely to be suspended. ${ }^{29}$ Chronic absenteeism and suspensions, in turn, are associated with lower test scores and grades as well as higher rates of grade retention and dropout. 30

Non-educational experiences like juvenile incarceration, mental health disorders, and early pregnancy or parenting, are all associated with lower educational attainment. ${ }^{31}$ Both homeless and foster youth are disproportionately likely to become involved with the criminal justice system. Homeless youth in particular are more likely to be stopped and arrested by police, in part because the act of being unhomed is often criminalized through loitering laws. ${ }^{2}$ Racial/ethnic minority youth are stopped more frequently than their white peers. 33 Additionally, one study found that 15 percent of incarcerated young adults ages 18-21 were former foster youth. 34 The risk of justice involvement is particularly high for foster youth in group homes or those with frequent placement changes. 35 The foster-care-to-prison pipeline can easily set students on a path away from college, especially given the limited postsecondary options in prisons. ${ }^{36}$ Foster youth are also more likely to have a mental health disorder at ages 17 or 18 , when they could be applying to or entering college. 37 Additionally, 44 percent of young women

\footnotetext{
${ }^{28}$ Erin S. Ingram, John M. Bridgeland, Bruce Reed, and Matthew Atwell, "Hidden in Plain Sight: Homeless Students in America's Public Schools." Civic Enterprises, 2017, https://files.eric.ed.gov/fulltext/ED572753.pdf.

${ }^{29}$ National Center for Homeless Education, "Supporting the Education of Unaccompanied Students Experiencing Homelessness," August 2017, https://files.eric.ed.gov/fulltext/ED594667.pdf; Ralph da Costa Nunez, Liz Cohen, and Katie Linek Puello, "Suspension Hubs: The Rise in Suspensions Among Homeless Students," Institute for Children, Poverty, and Homelessness, April 2018, https://www.icphusa.org/reports/suspensionhubs/\#students-residing-in-shelters-most-at-risk-of-suspension.

${ }^{30}$ National Center for Homeless Education, "Supporting the Education of Unaccompanied Students Experiencing Homelessness," August 2017, https://files.eric.ed.gov/fulltext/ED594667.pdf.

${ }^{31}$ Lance Lochner and Enrico Moretti, "The Effect of Education on Crime: Evidence from Prison Inmates, Arrests, and SelfReports," American Economic Review 94, no. 1 (2004): 155-189, www.doi.org/10.1257/000282804322970751; Daniel R. Hale and Russell M. Viner, "How Adolescent Health Influences Education and Employment: Investigating Longitudinal Associations and Mechanisms," Journal of Epidemiology and Community Health 72, no. 6 (2018): 465-47,

https://jech.bmj.com/content/72/6/465.abstract; Christina J. Diaz, and Jeremy E. Fiel, "The Effect(s) of Teen Pregnancy: Reconciling Theory, Methods, and Findings," Demography 53, no. 1 (2016): 85-116, https://doi.org/10.1007/s13524-015-0446-6.

32 Jerreed D. Ivanich and Tara D. Warner, "Seen or Unseen? The Role of Race in Police Contact among Homeless Youth," Justice Quarterly 36, no. 5 (2019): 816-840, https://doi.org/10.1080/07418825.2018.1463389.

${ }^{33}$ Ibid.

${ }^{34}$ Youngmin Yi and Christopher Wildeman, "Can Foster Care Interventions Diminish Justice System Inequality?" The Future of Children 28, no. 1 (2018): 37-58, https://www.jstor.org/stable/26641546.

35 Juvenile Law Center, "What is the Foster Care-to-Prison Pipeline?" May 26, 2018, https://jlc.org/news/what-foster-care-prisonpipeline.

${ }^{36}$ Meagan Wilson, Rayane Alamuddin, Danielle Cooper, "Unbarring Access: A Landscape Review of Postsecondary Education in Prison and Its Pedagogical Supports," Ithaka S+R, May 30, 2019, https://doi.org/10.18665/sr.311499.

${ }^{37}$ Judy R. Havlicek, Antonio R. Garcia, and Douglas C. Smith, "Mental Health and Substance Use Disorders among Foster Youth Transitioning to Adulthood: Past Research and Future Directions," Children and Youth Services Review 35, no. 1 (2013): 194-203, https://dx.doi.org/10.1016\%2Fj.childyouth.2012.10.003.
} 
who are homeless are pregnant or parenting, and youth in foster care are also more likely to become pregnant before 18 than their non-foster peers. ${ }^{38}$

Black homeless and foster youth are likely to be doubly disadvantaged, facing challenges within the education system related to their racial identity as well as their status as a homeless or foster youth. Due to persistent school segregation, Black students are likely to be concentrated in schools with inadequate resources and, like homeless and foster youth, routinely face more frequent disciplinary action. 39 UCLA's Black Male Institute examined this double disadvantage and revealed that Black foster youth in Los Angeles public schools were more likely to be suspended than to graduate and be eligible to attend a California state college. ${ }^{\circ 0}$ Similar patterns appear among Black homeless students in Seattle. ${ }^{41}$

For foster or homeless youth with multiple minority identities-such as being Black and identifying as LGBTQ-accessing necessary resources can be more difficult because of identitybased discrimination. ${ }^{42}$ Black and LGBTQ youth are at heightened risk of experiencing racial bias, sex- or gender-based discrimination, and family rejection. Therefore, these youth experience compounding layers of discrimination on top of the financial and socio-emotional challenges that can come with being homeless or in foster care. 43 The over-policing of both Black and LGBTQ individuals, and Black transgender women in particular, puts them especially at risk for dropping out as they face more school discipline and more frequent police contact. 44 As a result, Black LGBTQ homeless and foster youth face a greater risk of entering the school-to-

\footnotetext{
${ }^{38}$ Deborah V. Svoboda, Terry V. Shaw, Richard P. Barth, and Charlotte Lyn Bright, "Pregnancy and Parenting among Youth in Foster Care: A Review," Children and Youth Services Review 34, no. 5 (2012): 867-875, https://doi.org/10.1016/j.childyouth.2012.01.023.

${ }^{39}$ Michael Evangelist and H. Luke Shaefer, "No Place Called Home: Student Homelessness and Structural Correlates," Social Service Review 94, no. 1 (2020): 4-35, https://doi.org/10.1086/707569.

Travis Riddle and Stacey Sinclair, "Racial Disparities in School-Based Disciplinary Actions Are Associated With County-Level Rates of Racial Bias," Proceedings of the National Academy of Sciences 116, no. 17 (2019): 8255-8260, https://doi.org/10.1073/pnas.1808307116.

${ }^{40}$ Brianna M. Harvey, Kenyon Lee Whitman, Tyrone Howard, and The Black Male Institute Lab, "The Disenfranchisement of Black Foster Youth: An Analysis of Los Angeles County Public School Data," (2020), https://blackmaleinstitute.org/thedisenfranchisement-of-black-foster-youth/.

${ }^{41}$ Amanda Ragnauth, "Disparities in Discipline: Making Sure Seattle's Homeless Students Aren't Left Behind," Institute for Children, Poverty, \& Homelessness (2017), https://www.icphusa.org/commentary/disparities-discipline-making-sure-seattles-homelessstudents-arent-left-behind/.

${ }^{42}$ Earl J. Edwards, "Young, Black, Successful, and Homeless: Examining the Unique Academic Challenges of Black Students who Experienced Homelessness," Journal of Children and Poverty 26, no. 2 (2020): 125-149, https://doi.org/10.1080/10796126.2020.1776688.

William G. Tierney and James Dean Ward. "Coming Out and Leaving Home: A Policy and Research Agenda for LGBT Homeless Students," Educational Researcher 46, no. 9 (2017): 498-507, https://doi.org/10.3102\%2F0013189X17733964.

43 Jevay Grooms, "No Home and No Acceptance: Exploring the Intersectionality of Sexual/Gender Identities (LGBTQ) and Race in the Foster Care System," The Review of Black Political Economy 47, no. 2 (2020): 177-193, https://doi.org/10.1177\%2F0034644620911381.

44 Jevay Grooms, "No Home and No Acceptance: Exploring the Intersectionality of Sexual/Gender Identities (LGBTQ) and Race in the Foster Care System," The Review of Black Political Economy 47, no. 2 (2020): 177-193, https://doi.org/10.1177\%2F0034644620911381; Tracey G. Scherr, "Educational Experiences of Children in Foster Care: MetaAnalyses of Special Education, Retention and Discipline Rates," School Psychology International 28, no. 4 (2007): 419-436, https://doi.org/10.1177\%2F0143034307084133; Youngmin Yi and Christopher Wildeman, "Can Foster Care Interventions Diminish Justice System Inequality?" The Future of Children 28, no. 1 (2018): 37-58, https://www.jstor.org/stable/26641546.
} 
prison pipeline. Importantly, foster and homeless youth with multiple layers of identity-based discrimination will need greater levels of resilience to persevere through their educational trajectories. 45

\section{Postsecondary experiences}

Regardless of race and ethnicity, students experiencing homelessness are about half as likely as students who have never experienced homelessness to complete at least some college credits. ${ }^{46}$ When foster and homeless youth do enter college, they are likely to continue facing challenges that make enrolling in and completing a degree or certificate extremely difficult. In particular, meeting basic needs such as food and housing remains a barrier for a substantial share of college students. Six in 10 college students surveyed at two-year colleges and nearly half of students surveyed at four-year colleges reported experiencing housing insecurity. ${ }^{47}$ Similarly, more than half of respondents at two-year colleges and 44 percent of respondents at four-year institutions reported being worried about running out of food. $4^{8}$ There are apparent racial and ethnic disparities amongst students experiencing food insecurity as well. The share of Black students identifying as food insecure was 19 percentage points higher than the share of white students.49 Beyond undermining students' overall wellbeing, a lack of access to basic needs substantially threatens students' educational progress.

While in college, homeless and foster youth often have limited access to the academic and nonacademic supports they need. In some cases, these individuals do not know how to access such supports or avoid accessing them in order to hide their homeless or foster status.50 Many institutions' inability to accurately assess the size of their homeless and foster youth populations exacerbates this problem. In K-12, the federal government requires states and districts to track and report on foster and homeless youth outcomes, but neither colleges nor states are required to track postsecondary students who are homeless or prior foster youth.

\footnotetext{
${ }^{45}$ William G. Tierney and James Dean Ward. "Coming Out and Leaving Home: A Policy and Research Agenda for LGBT Homeless Students," Educational Researcher 46, no. 9 (2017): 498-507, https://doi.org/10.3102\%2F0013189X17733964; Earl J. Edwards, "Young, Black, Successful, and Homeless: Examining the Unique Academic Challenges of Black Students who Experienced Homelessness," Journal of Children and Poverty 26, no. 2 (2020): 125-149, https://doi.org/10.1080/10796126.2020.1776688; Laura Baams, Bianca DM Wilson, and Stephen T. Russell, "LGBTQ Youth in Unstable Housing and Foster Care," Pediatrics 143, no. 3 (2019), https://pediatrics.aappublications.org/content/pediatrics/143/3/e20174211.full.pdf.

${ }^{46}$ M. A. Kull, M. H. Morton, S. Patel, S. Curry, and E. Carreon. "Missed Opportunities: Education among Youth Experiencing Homelessness in America." Chapin Hall at the University of Chicago, November 2019, https://eric.ed.gov/?id=ED603015.

${ }^{47}$ Sara Goldrick-Rab, Christine Baker-Smith, Vanessa Coca, Elizabeth Looker, and Tiffani Williams, "College and University Basic Needs Insecurity: A National \#RealCollege Survey Report," The Hope Center, April 2019, https://hope4college.com/wpcontent/uploads/2019/04/HOPE realcollege National report digital.pdf.

${ }^{48}$ Ibid.

${ }^{49}$ Ibid.

${ }^{50}$ Alana R. Kinarsky, "Fostering Success: Understanding the Experience of Foster Youth Undergraduates," Children and Youth Services Review 81 (2017): 220-228, https://doi.org/10.1016/j.childyouth.2017.08.016.

Ronald E. Hallett and Adam Freas, "Community College Students' Experiences with Homelessness and Housing Insecurity," Community College Journal of Research and Practice 42, no. 10 (2018): 724-739,

https://doi.org/10.1080/10668926.2017.1356764.
} 
Many college students rely on social and familial supports to succeed. Homeless and foster youth, however, have fewer family ties, and their social connections on campus tend to be weaker than their peers. ${ }^{11}$ Developing social supports, especially peer networks, is important for homeless and foster youth to persist and graduate. These social supports, as well as involvement in campus activities and setting clear goals, are critical for developing the resiliency homeless and foster youth need to succeed in higher education..$^{2}$

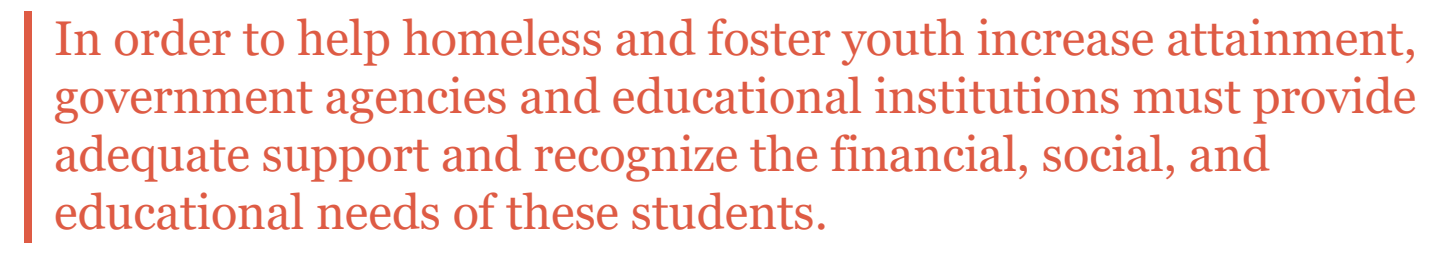

Although homeless and foster youth face a number of challenges throughout the education pipeline, attending college facilitates their transition into adulthood and helps students plan for a future.53 As such, it is important that these youth have the opportunity to pursue a postsecondary credential. In order to help homeless and foster youth increase attainment, government agencies and educational institutions must provide adequate support and recognize the financial, social, and educational needs of these students. These supports must consider the unique situation of doubly disadvantaged youth who face challenges related to their racial/ethnic identity and foster or homeless status.

\section{What is the current policy landscape, including actors and policies?}

Federal, state, and local policies and associated programs impact homeless and foster youth in a variety of ways. The distribution of which level of government administers services creates a complicated web for homeless and foster youth to navigate. The decentralization can also create scenarios where needs are unmet and inefficiencies arise. We provide an overview of noneducation policies designed to aid homeless and foster youth. We then explain how homeless and foster youth interaction with federal, state, and local education policies and programs. Finally, we identify policy gaps and specific shortcomings of education and social welfare programs that may hinder homeless and foster youth's educational success.

\footnotetext{
${ }^{51}$ Kim Skobba, David Meyers, and Lori Tiller, "Getting By and Getting Ahead: Social Capital and Transition to College among Homeless and Foster Youth," Children and Youth Services Review 94 (2018): 198-206, https://doi.org/10.1016/j.childyouth.2018.10.003.

${ }^{52}$ Michael Hass and Kelly Graydon, "Sources of Resiliency among Successful Foster Youth," Children and Youth Services Review 31, no. 4 (2009): 457-463, https://doi.org/10.1016/j.childyouth.2008.10.001; Kim Skobba, David Meyers, and Lori Tiller, "Getting By and Getting Ahead: Social Capital and Transition to College among Homeless and Foster Youth," Children and Youth Services Review 94 (2018): 198-206, https://doi.org/10.1016/i.childyouth.2018.10.003.

53 Jarrett T. Gupton, "Campus of Opportunity: A Qualitative Analysis of Homeless Students in Community College," Community College Review 45, no. 3 (2017): 190-214, https://doi.org/10.1177\%2F0091552117700475.
} 


\section{Non-educational policies}

Federal, state, and local governments each play important and distinct roles in homeless and foster youth. Child welfare and housing programs are two important non-educational spending categories that benefit homeless and foster youth. Because funding for these services comes from a mix of federal, state, and local dollars, and programs are administered at varying levels of government, eligibility criteria varies across programs and jurisdictions. This variation creates a complicated system for youth to navigate. Here we provide an overview of how child welfare and housing services are administered to homeless and foster youth.

\section{Child welfare services}

As the primary entity responsible for ensuring children's welfare, states play a particularly important role in supporting foster youth. ${ }^{4}$ However, a combination of state and local agencies administer child welfare services. Although the federal government provides guidance on how to administer services to homeless and foster youth, state and local authorities have autonomy in the process. This means youth not only experience different systems across states, but the child welfare system can vary within a state and thus youth have different experiences if they move around. This means that highly-mobile youth may transition between locally assigned case workers, which can disrupt the continuity of care.

Because federal, state, and local governments fund services, the eligibility in any given jurisdiction will depend on the mix of those funding sources. For example, the federal government requires that services be provided to foster youth up to age 18, but the majority of states have extended coverage beyond that point. 55 Research suggests that extended foster care can increase college going among foster youth. ${ }^{56}$

\section{Housing services}

As discussed above, secure and reliable housing is important for youth to succeed at schooling and to establish long-term stability into adulthood. As youth age out of foster care, federal and state programs assist in transition housing. After the age of 18 , youth may remain in foster care, if that is an option in their state, or may start the transition out of foster care. While some youth may fully leave the system others enter state supported "supervised independent living settings," which may include dormitories, semi-supervision apartments, or other shared housing.57 Under Title IV-E of the Social Security Act (SSA), states may seek reimbursement from the federal government for providing foster youth up to age 23 with additional care or transition housing. States can also obtain federal funding under the SSA's John H. Chafee Foster Care

\footnotetext{
${ }^{54}$ Adrienne L. Fernandes-Alcantara, "Youth Transitioning from Foster Care: Background and Federal Programs," Library of Congress, Congressional Research Service, May 29, 2019, https://fas.org/sgp/crs/misc/RL34499.pdf. 
Independence Program (the Chaffee program) to provide housing for foster youth and former foster youth attending college. $5^{8}$

The Runaway and Homeless Youth Act (RHYA) is federal legislation that supports unaccompanied homeless youth specifically. RHYA houses the Transitional Living Program, which seeks to "provide a temporary safety net and strong emotional support system for young people to transition into self-sufficiency." 59 For youth ages 16-22 who are unable to live with their families, the Transitional Living Program provides funding for a range of services, including safe housing and postsecondary education and training opportunities. ${ }^{60}$ The federal government provides funding for these housing programs, but distributes the money to a range of providers through a competitive application process. These housing providers include state and local agencies as well as private organizations. The myriad ways in which foster and homeless youth can secure government funded housing underscores the complicated web of services these youths must navigate.

\section{Education policies}

The McKinney-Vento Homeless Assistance Act is the primary piece of federal legislation supporting the education of youth experiencing homelessness and requires that "homeless students must have access to the same public education provided to other students, including access to any programs and services for which they meet eligibility requirements."61 McKinneyVento requires all PK-12 school districts to have a homeless education liaison, whose role it is to support the educational success of homeless youth. McKinney-Vento primarily addresses the educational rights of K-12 students, but also directly and indirectly impacts homeless students' postsecondary options. Supporting homeless youth in PK-12 is necessary to increase their postsecondary opportunities. The liaison more explicitly helps homeless youth by helping them complete admissions materials and their Free Application for Federal Student Aid (FAFSA). 62

The College Cost and Reduction Act of 2007 (CCRAA) is another piece of federal legislation that supports access to higher education for unaccompanied homeless youth. CCRAA amends the Higher Education Act and allows unaccompanied homeless youth - who may not have access to their parents' financial information-to apply for federal financial aid as an independent student, rather than a dependent student. This is important because without federal aid, these youths are unlikely to be able to afford college. Homeless and foster youth often have complicated, strained, or no relationships with their families and thus may not be able to complete FAFSA forms without the CCRAA caveat. Of course, the success of this policy hinges

\footnotetext{
${ }^{58}$ Adrienne L. Fernandes-Alcantara, "Youth Transitioning from Foster Care: Background and Federal Programs," Library of Congress, Congressional Research Service, May 29, 2019, https://fas.org/sgp/crs/misc/RL34499.pdf.

${ }^{59}$ Family and Youth Services Bureau, "Transitional Living Program Fact Sheet," September 2020, https://www.acf.hhs.gov/fysb/factsheet/transitional-living-program-fact-sheet.

$60 \mathrm{lbid}$.

${ }^{61}$ Micah Ann Wixom, "State and Federal Policy: Homeless Youth," Education Commission of the States, October 31, 2016, https://www.ecs.org/state-and-federal-policy-homeless-youth/.

62 US Department of Education, "I Want to Go to College: Now What?" December 2018, https://www2.ed.gov/programs/homeless/want-to-go-to-college.pdf.
} 
on whether or not homeless youth are aware of this, and if their McKinney-Vento liaisons and other social service case managers both inform them of the policy and help them navigate the system.

The aforementioned federal Chafee program, which helps provide housing for foster youth transitioning to adulthood, also provides these youth with education grants. The Education and Training Voucher (ETV) program, which provides up to \$5,000 per year in funding for foster youth to attend higher education for up to five years. ${ }^{63}$ The federal government allocates ETV funding to states based on their proportion of the national foster youth population. Additionally, states must match 20 percent of the federal allocation. States then administer the ETV grants themselves, or in some cases contract with private organizations to administer the funds. As such, there is variation across states in the process for foster youth to secure this funding. This variation includes whether the awards go directly to the student or are applied to the institution, similar to a Pell grant; or if the award is last-dollar, awarded to cover any need remaining after all other financial aid is administered, or first-dollar, which is awarded before other forms of aid. 64 These design differences impact whether a student can only use the grant to cover tuition and fees, or if they can use it to pay for other education-related needs such as transportation, books, and food. Research suggests that foster youth in California who receive a grant through the ETV program persist in college at higher rates than foster youth who do not receive the grant. ${ }^{65}$ Additional research is necessary to evaluate the effectiveness of these federal allocations and the state-specific approaches to administering Chafee dollars. ${ }^{66}$

In addition to legislation geared directly towards homeless and foster youth, both populations are also eligible for federal higher education programs such as TRIO, which serve low-income students more broadly. During the 2008 reauthorization of the Higher Education Act, foster and homeless youth became automatically eligible for TRIO programs including Talent Search, Upward Bound, Student Support Services, Educational Opportunity Centers, and Gaining Early Awareness and Readiness for Undergraduate Programs (GEAR-UP). ${ }^{67}$ These cost-effective

\footnotetext{
${ }^{63}$ Adrienne L. Fernandes-Alcantara, "Youth Transitioning from Foster Care: Background and Federal Programs," Library of Congress, Congressional Research Service, May 29, 2019, https://fas.org/sgp/crs/misc/RL34499.pdf.

${ }^{64}$ Robin Nixon and Maria Garin Jones, “The Chafee Educational and Training Voucher (ETV) Program: Six States' Experiences,” National Foster Care Coalition, 2007,

https://www.fostercareandeducation.org/DesktopModules/Bring2mind/DMX/Download.aspx?Entryld=1241\&Command=Core Downl oad\&method=inline\&Portalld $=0$ \&Tabld $=124$.

${ }^{65}$ Nathanael J. Okpych, Sunggeun Ethan Park, Samiya Sayed, and Mark E. Courtney, "The Roles of Campus-Support Programs (CSPs) and Education and Training Vouchers (ETVs) on College Persistence for Youth with Foster Care Histories," Children and Youth Services Review 111 (2020), https://doi.org/10.1016/j.childyouth.2020.104891; Robin Nixon and Maria Garin Jones, "The Chafee Educational and Training Voucher (ETV) Program: Six States' Experiences," National Foster Care Coalition, 2007, https://www.fostercareandeducation.org/DesktopModules/Bring2mind/DMX/Download.aspx?Entryld=1241\&Command=Core Downl oad\&method=inline\&Portalld=0\&Tabld $=124$.

${ }^{66}$ Robin Nixon and Maria Garin Jones, “The Chafee Educational and Training Voucher (ETV) Program: Six States' Experiences,” National Foster Care Coalition, 2007,

https://www.fostercareandeducation.org/DesktopModules/Bring2mind/DMX/Download.aspx?Entryld=1241\&Command=Core Downl oad\&method=inline\&Portalld $=0$ \&Tabld $=124$.

${ }^{67}$ Barbara Duffield, "Higher Education Opportunity Act: Homeless and Foster Youth," National Association for the Education of Homeless Children and Youth, 2017, https://naehcy.org/wp-content/uploads/2017/12/hea summ.pdf.
} 
programs have an established track record of improving postsecondary access for qualified students. 68

The majority of state higher education policies relating to foster and homeless youth aim to provide tuition assistance and financial support. Currently, 38 states offer tuition waivers, grant programs, or scholarships to current or former foster youth. ${ }^{69}$ These policies vary significantly in terms of program design, eligibility criteria for foster youth, and the amount of aid awarded. Although we know financial aid improves lower-income students' access and postsecondary success, there is limited research into the effects of programs specifically targeting foster youth. One study examining the Texas tuition waiver found that foster youth who receive the award are 3.5 times more likely to complete a bachelor's degree than those without the tuition waiver. The same study found that that fewer than half of the eligible youth use the waiver.70

To maximize the benefits of state programs, we need more and better evidence about the specific policy characteristics associated with strong student outcomes and high levels of utilization. Moreover, the mix of state programs with Chafee-funded grants creates a complicated system for youth to navigate, and may create inefficiencies in government spending.

While states have passed legislation to support homeless youth in the K-12 system they have provided little to no funding explicitly for homeless youth in college or seeking to enroll in college. Because of the foster-to-homeless pipeline, some homeless youth are eligible for the aforementioned foster youth state financial aid programs. Developing programs to support homeless youth who have not been in the foster system is an important next step to ensuring all homeless youth receive the assistance they need to be successful in college.

\section{Policy effectiveness and gaps}

One of the biggest challenges for schools and colleges seeking to support homeless students is their lack of information about homeless students. In the PK-12 system, the McKinney-Vento Act requires school districts to identify and support students experiencing homelessness.

However, districts struggle to obtain accurate counts because some students and families are not comfortable disclosing their status. A recent study found that some students are hesitant to disclose their homeless status to school staff due to hostile racial climates. ${ }^{71}$ Given the

\footnotetext{
${ }^{68}$ Eleanor L. Harvill, Rebecca A. Maynard, Hoa TH Nguyen, Claire Robertson-Kraft, and Namrata Tognatta, "Effects of College Access Programs on College Readiness and Enrollment: A Meta-Analysis," Society for Research on Educational Effectiveness, 2012, https://eric.ed.gov/?id=ED530404; Henry M. Levin, Clive Belfield, Fiona Hollands, A. Brooks Bowden, Henan Cheng, Robert Shand, Yilin Pan, and Barbara Hanisch-Cerda, "Cost-Effectiveness Analysis of Interventions that Improve High School Completion," Teacher College, Columbia University, October 2012, http://citeseerx.ist.psu.edu/viewdoc/download?doi=10.1.1.397.125\&rep=rep1\&type=pdf.

${ }^{69}$ University of Washington, "Tuition Waivers by State," 2021, https://depts.washington.edu/fostered/tuition-waivers-state.

70 Toni Watt and Monica Faulkner, "The Texas Tuition and Fee Waiver Program for Youth Who Have Experienced Foster Care: An Assessment of Waiver Utilization and Impact," Children and Youth Services Review 117 (2020), https://doi.org/10.1016/j.childyouth.2020.105285.

${ }^{71}$ Earl J. Edwards, "Young, Black, Successful, and Homeless: Examining the Unique Academic Challenges of Black Students who Experienced Homelessness," Journal of Children and Poverty 26, no. 2 (2020): 125-149, https://doi.org/10.1080/10796126.2020.1776688.
} 
disproportionate impact homelessness has on Black students, a school's ability to foster a positive racial climate and empower students to disclose their status to adults is critical to obtaining an accurate count. At the postsecondary level, counting homeless students is even more difficult. The federal government does not explicitly require colleges and universities to identify or support homeless students. ${ }^{72}$ Roughly 58,00o college students indicate they are homeless on their FAFSA, and colleges can use this disclosure to identify and serve homeless youth on their campuses. 73 However, homeless college students face social stigmas related to their status and thus may be hesitant to identify themselves on campus. Improving the accurate identification of homeless students in both the PK-12 and higher education contexts is an important first step towards providing these youth with beneficial services.

For both foster and homeless youth, restrictive eligibility criteria for education and noneducational services and programs may limit students' access to the services and support they need to be successful in college. For instance, foster youth are able to use their federal Education and Training Vouchers (ETV) to attend college until the age of 23, but only if they apply for these funds prior to turning 21. Therefore, foster youth who begin college after turning 21 are ineligible for the voucher.74 For homeless or foster youth experiencing food insecurity, restrictive eligibility criteria also make it difficult to access food stamps through SNAP. As a result, the majority of college students are ineligible for SNAP unless they work at least 20 hours per week, which may not be feasible for students enrolled full-time. 75 Given Black students are disproportionately likely to experience food insecurity, there are clear racial equity implications for ensuring that anti-poverty programs such as SNAP are accessible to college students in need.

Even foster and homeless youth who are eligible for services can have difficulty accessing them. While some students may be exempt from the SNAP work requirements, students may not access their benefits due to confusing guidelines around eligibility and perceived stigma around food stamps. A 2018 study found that nearly two million students eligible for SNAP benefits in 2016 did not receive them. ${ }^{76}$ For homeless students, financial aid is particularly necessary to go to college. Although the CCRAA allows unaccompanied homeless youth to qualify as "independent," these students still have to provide documentation verifying their status as unaccompanied and homeless. Homeless youth who do not live in a shelter (e.g., those on the street or living in a car), face difficulties providing verification of their homeless status. ${ }^{77}$

\footnotetext{
72 Brialle D. Ringer, "College Students Experiencing Homelessness: The Consequence of Failed Macro Policies," McNair Scholars Research Journal 8, no. 1 (2015), https://commons.emich.edu/mcnair/vol8/iss1/9/.

${ }^{73}$ Susan Frick, "Invisible Struggles: What Can Be Done to Help College Students Experiencing Homelessness?" Pegasus: The Magazine of the University of Central Florida (2015), https://www.ucf.edu/pegasus/invisible-struggles/.

${ }^{74} \mathrm{GAO}$, "Actions Needed to Improve Access to Federal Financial Assistance for Homeless and Foster Youth," May 19, 2016, https://www.gao.gov/products/GAO-16-343.

${ }^{75}$ Rosa Rada, "For Some College Students, Hunger Is an Extracurricular," National Conference of State Legislatures, April 13, 2018, https://www.ncsl.org/blog/2018/04/13/for-some-college-students-hunger-is-an-extracurricular.aspx.

${ }^{76}$ Kathryn Larin, "Food Insecurity: Better Information Could Help Eligible College Students Access Federal Food Assistance Benefits. Report to Congressional Requesters. GAO-19-95," US Government Accountability Office, December 21, 2018, https://www.gao.gov/products/GAO-19-95?mobile opt out=1.

${ }^{77}$ Rashida M Crutchfield, Ruth M. Chambers, and Barbara Duffield, "Jumping through the Hoops to Get Financial Aid for College Students Who Are Homeless: Policy Analysis of the College Cost Reduction and Access Act of 2007," Families in Society 97, no. 3 (2016): 191-199, https://doi.org/10.1606\%2F1044-3894.2016.97.25.
} 
Implicit bias of service providers may also hamper attempts to access resources by students from marginalized communities.

\section{Recommendations to policymakers}

Homeless and foster youth face unique challenges in accessing, affording, and completing higher education. These challenges are primarily the culmination of barriers they faced throughout their PK-12 education, but the postsecondary sector has its own unique challenges. Black and Hispanic students are disproportionately affected by the barriers to postsecondary access and success, both because they are disproportionately represented in the homeless and foster youth populations and because they face discrimination and bias off campus, too. Creating policies to address the needs of foster and homeless youth not only meet our moral obligation of serving these students but can also contribute to closing racial and ethnic equity gaps in postsecondary access and attainment.

To meet the unique needs of homeless and foster youth, we provide the following recommendations to policymakers:

1. State financial aid programs should include academic and career counseling. When financial aid recipients receive this added guidance, they persist and complete their college degree at higher rates. These academic and career counselors should also help homeless and foster youth who are in college access other services, such as housing and food benefits. Because many states already have established foster youth financial aid programs, we recommend advising services build on these existing policies. We believe states are best positioned to manage these programs in order to meet the needs of their unique contexts. For states that do not have foster youth postsecondary programs, we recommend creating one in alignment with above guidance.

a. Although variation across states is expected in order to meet the unique needs of certain states, we recommend states universally lift requirements to enter a postsecondary institution by a certain age in order to be eligible for financial aid programs. Given that foster and homeless youth face unique K-12 challenges and some are likely to complete high school or their GED later than age 18, states that require students to enroll in college by age 21 in order to be eligible for targeted financial aid programs may be hampering the opportunities for some youth.

2. We recommend that state governments expand foster youth postsecondary supports to include homeless youth. Some homeless youth who were previously in the foster system can already access these benefits, but there are limitations based on when the student was in the foster system and for how long. Expanding programs to include all homeless youth provides these students with benefits regardless of the nature of their relationship with the foster system.

a. States should also loosen the eligibility rules for foster students. To be eligible for foster financial aid programs, many states consider the length of time the student spent in the foster system, their care status at age 18, or the age at which they left the foster system. Instead, states should include any student who was ever foster- 
involved. The effects of homelessness and foster care are not limited only to a youth's time spent in such a situation, and thus states should widen program eligibility to include more impacted students.

3. Faculty, administrators, and state employees may have implicit biases against homeless and foster youth as well as racial/ethnic minority youth. Multiple layers of bias can disproportionately harm homeless and foster youth from marginalized communities. States should provide comprehensive training to individuals working with homeless and foster youth to combat personal biases and ensure all eligible youth receive appropriate services. It is prudent to include homeless and foster youth from a range of backgrounds into the development of such trainings to ensure the training reflects these students' unique needs. Because homeless and foster youth are vulnerable populations, it is important that an independent group, such as an inspector general, actively monitors service providers to ensure appropriate treatment.

4. State policymakers should prioritize the evaluation of the current and planned financial aid policies targeted towards foster and homeless youth. Evaluations should examine the effectiveness of such programs to improve access and attainment for homeless and foster you. Evaluators should assess whether policy effects vary across student demographics in order to recommend changes that promote equity.

5. Finally, it is important for state and federal governments to collect better data on foster and homeless youth. We recommend the federal government mandate postsecondary institutions collect data that includes enrollments and outcomes for homeless and foster youth. We also suggest states work to better identify homeless and foster youth throughout the PK-20 education sector, and include this information in state longitudinal data systems. Researchers and evaluators need these data to evaluate programs and policies. Additionally, individual-level data can help identify youth who move in and out of homelessness and the foster system and thus facilitate the active outreach from higher education departments to provide financial aid services and make youth aware of their eligibility for such programs. 